\title{
PENGARUH KEPEMILIKAN MANAJERIAL DAN KEPEMILIKAN INSTITUSIONAL TERHADAP NILAI PERUSAHAAN PADA PERUSAHAAN MANUFAKTUR YANG TERDAFTAR DI BEI
}

\author{
Neni Marlina Br Purba ${ }^{1}$, Syahril Effendi ${ }^{2}$ \\ Dosen Program Studi Akuntansi Universitas Putera Batam \\ email: nenimarlina05@gmail.com
}

\begin{abstract}
This study aims to determine the effect of managerial ownership and institutional ownership on firm value in manufacturing companies listed on the Indonesian stock exchange. The method used is quantitative. Based on multiple linear regression analysis managerial ownership and institutional ownership variables of firm value obtained $Y=1,419+0,014 X 1+1,158 X 2+e$. Partially managerial ownership variables do not have a significant effect on firm value. Whereas institutional ownership has a significant influence on company value. From the results of the simultaneous test, it was found that managerial ownership and institutional ownership together had a significant effect on firm value, while the coefficient of determination obtained by Adjusted $R$ Square was 0.201. This means that the ability of managerial ownership and institutional ownership variables in explaining the dependent variable is $20.1 \%$ and the remaining $79.9 \%$ is explained by other variables.
\end{abstract}

Keywords: Managerial ownership, institutional ownership and company value.

\section{PENDAHULUAN}

Pada dasarnya semua perusahaan mempunyai tujuan yang sama yaitu untuk memperoleh keuntungan. Seorang manajer perusahaan memiliki peran yang sangat penting dalam pengambilan keputusan untuk memperoleh keuntungan serta meningkatkan nilai perusahaan. Karena, semakin besar keuntungan yang diperoleh perusahaan, makan akan semakin meningkatkan nilai perusahaan dimata para pemegang saham, hal ini juga akan meningkatkan kemakmuran para pemegang saham sehingga para pemegang saham semakin yakin untuk menginvestasikan saham pada perusahaan tersebut.

Manajer sangat berperan penting didalam mengambil suatu keputusan untuk kebijakan perusahaan dalam memaksimalkan keuntungan dan nilai perusahaan serta memakmurkan para pemegang saham. Struktur kepemilikan (kepemilikan manajerial dan kepemilikan institusional) oleh beberapa peneliti dipercaya mampu mempengaruhi jalanya perusahaan yang pada akhirnya berpengaruh pada kinerja perusahaan dalam mencapai tujuan perusahaan yaitu memaksimalkan nilai perusahaan. Hal ini disebabkan karena adanya control yang mereka milik terhadap perusahaan.

Kepemilikan manajerial adalah kepemilikan saham sekaligus sebagai pihak manajemen perusahaan. Kepemilikan saham manajerial dapat digunakan untuk mensejalankan antara kepentingan pemegang saham dengan manajer. Sebagai pemilik perusahaan sekaligus sebagai manajer pada perusahaan tersebut, maka manajer akan ikut merasakan langsung manfaat dari kebijakan yang diambil untuk perusahaan dan manajer juga akan ikut menanggung risiko apabila ada kerugian yang timbul sebagai konsekuensi dari pengambilan keputusan yang salah, tetapi sebaliknya manajer juga akan dapat ikut mersakan keuntungan perusahaan apabila kebijakan yang diambil berpengaruh positif terhadap perusahaan. Semakin besar proporsi kepemilikan manajemen pada perusahaan akan dapat 
menyatukan kepentingan antara manajer dengan pemegang saham, sehingga diharapkan dapat meningkatkan nilai dan kinerja perusahaan.

Melalui kepemilikan institusional, efektivitas pengelolaan sumber daya perusahaan oleh manajemen dapat diketahui dari informasi yang dihasilkan melalui reaksi pasar atas pengumuman laba. Kepemilikan institusional memiliki kemampuan untuk mengendalikan pihak manajemen melalui proses monitoring secara efektif sehingga mengurangi tindakan kecurangan manajemen dalam perusahaan. Dengan adanya persentase kepemilikan institusional diharapkan perusahaan lebih dapat terkontrol dari pihak luar bukan saja dari pihak manajerial sehingga manajemen laba yang diperoleh dapat dilaporkan dengan baik. Persentase saham tertentu yang dimiliki oleh institusi dapat mempengaruhi proses penyusunan laporan keuangan yang tidak menutup kemungkinan terdapat akrualisasi sesuai kepentingan pihak manajemen (Boediono, 2005).

Konflik muncul ketika terjadi pemisahan antara kepemilikan dan pengelolaan suatu perusahaan atau yang sering disebut dengan konflik keagenan. Konflik terjadi tidak lepas dari pihak menejer yang ingin mengambil keutungan sendiri tanpa memperdulikan keuntungan pihak lain atau pihak pemilik, karena menjer beranggapan bahwa kemakmuran pihak pemilik sangat besar dibandingkan dengan kemakmuran menejer yang di peroleh dari kompensasi gaji.

Moh'd, et al (1998) dalam Sofyaningsih dan Hardiningsih (2011) berpendapat bahwa untuk meminimalkan terjadinya konflik keagenan dapat dilakukan dengan peningkatan kepemilikan saham oleh pihak institusi sebagai pihak yang memonitor agen. Investor institusional (misalnya perusahaan asuransi, bank, perusahaan investasi dan kepemilikan oleh institusi lain) dalam suatu perusahaan akan menyebabkan distribusi saham akan lebih menyebar yang nantinya mendorong peningkatan pengawasan yang lebih optimal terhadap kinerja manajemen. Shleifer dan Vishny (1986) dalam Pakaryaningsih (2008) berpendapat bahwa tingkat kepemilikan institusional dalam proporsi yang cukup besar akan mempengaruhi nilai pasar perusahaan. Dasar argumentasi ini adalah semakin besar tingkat kepemilikan saham oleh institusi, maka semakin efektif pula mekanisme kontrol terhadap kinerja manajemen.

Nilai perusahaan merupakan persepsi investor terhadap tingkat keberhasilan perusahaan dalam mengelola sumber daya pada akhir tahun berjalan yang tercermin pada harga saham perusahaan. Semakin tinggi harga saham semakin tinggi pula nilai perusahaan sebaliknya semakin rendah harga saham maka nilai perusahaan juga rendah atau kinerja perusahaan kurang baik. Dalam penelitian ini, pengukuran nilai perusahaan menggunakan Price Book Value (PBV). Tujuan umum dari suatu perusahaan adalah mengembangkan usahanya dan memberikan kemakmuran yang maksimal kepada para pemegang sahamnya serta mengoptimalkan nilai perusahaan. Jika kemakmuran pemegang saham terjamin maka sudah pasti nilai dari perusahaan tersebut meningkat, dan kemakmuran pemegang saham ini akan dapat meningkat apabila harga saham yang dimilikinya juga meningkat. Dengan kata lain, bagi perusahaan yang menerbitkan saham di pasar modal, harga saham yang ditransaksikan dibursa merupakan indikator nilai perusahaan. Nilai pasar saham dihitung dengan menggunakan rasio Price Book Value (PBV).

\section{TINJAUAN PUSTAKA \\ Nilai Perusahaan}

Nilai perusahaan yang baik merupakan tujuan semua perusahaan. Semakin baiknya nilai perusahaan, maka akan semakin besar kemungkinan perusahaan memperoleh keuntungan dan semakin makmur para pemilik/pemegang saham. Nilai perusahaan dalam penelitian ini didefinisikan sebagai nilai pasar. Karena nilai perusahaan dapat memberikan kemakmuran pemegang saham secara maksimum apabila harga saham perusahaan meningkat. Semakin tinggi harga saham, maka makin tinggi kemakmuran pemegang saham. Untuk mencapai nilai perusahaan umumnya para pemodal menyerahkan pengelolaannya kepada para profesional. Para profesional diposisikan sebagai manajer ataupun komisaris. 
Kinerja keuangan akan menentukan tinggi rendahnya harga saham dipasar modal. Berarti nilai perusahaan juga ditentukan oleh kinerja keuangan perusahaan Apabila kinerja keuangan perusahaan baik, maka sahamnya akan diminati investor dan harganya meningkat. Dengan meningkatnya harga saham maka nilai perusahaaan dimata investor juga meningkat.

\section{Kepemilikan Manajerial}

Dari sudut pandang teori akuntansi, manajemen perusahaan sangat ditentukan oleh kinerja manajer perusahaan. Kebijakan yang diberikan manajer akan menentukan besar atau kecilnya laba yang akan dihasilkan perusahaan. Kebijakan manajer juga dipengaruhi kedudukannya didalam perusahaa, jika manajer tersebut sekaligus sebagai pemegang saham dan manajer yang bukan sebagai pemegang saham. Dua hal ini akan mempengaruhi manajemen perusahaan sebab kepemilikan seorang manajer akan ikut menentukan kebijakan dan pengambilan keputusan terhadap kinerja perusahaan yang dikelola. Kepemilikan manajemen terhadap saham perusahaan dipandang dapat menyelaraskan potensi perbedaan kepentingan antara pemegang saham luar dengan manajemen sehingga permasalahan keagenan diasumsikan akan hilang apabila seorang manajer adalah juga sekaligus sebagai pemilik. Semakin besar proporsi kepemilikan saham manajemen pada perusahaan maka manajemen cenderung berusaha lebih giat untuk kepentingan pemegang saham yang tidak lain adalah dirinya sendiri.

\section{Kepemilikan Institusional}

Kepemilikan institusional adalah kepemilikan saham perusahaan yang dimiliki oleh institusi atau lembaga seperti perusahaan asuransi, bank, perusahaan investasi dan kepemilikan institusi lain (dalam Tarjo, 2011). Kepemilikan institusional memiliki arti penting dalam memonitor manajemen karena dengan adanya kepemilikan oleh institusional akan mendorong peningkatan pengawasan yang lebih optimal. Monitoring tersebut tentunya akan menjamin kemakmuran untuk pemegang saham, pengaruh kepemilikan institusional sebagai agen pengawas ditekan melalui investasi mereka yang cukup besar dalam pasar modal. Semakin besar kepemilikan oleh institusi keuangan maka semakin besar pula kekuatan suara dan dorongan untuk mengoptimalkan nilai perusahaan. Kepemilikan institusional memiliki kelebihan antara lain: 1) Memiliki profesionalisme dalam menganalisis informasi sehingga dapat menguji keandalan informasi. 2) Memiliki motivasi yang kuat untuk melaksanakan pengawasan lebih ketat atas aktivitas yang terjadi di dalam perusahaan.

\section{Kerangka Konseptual}

Berdasarkan penelitian yang telah disampaikan sebelumnya, maka berikut ini dapat dikemukakan kerangka konseptual penelitian.

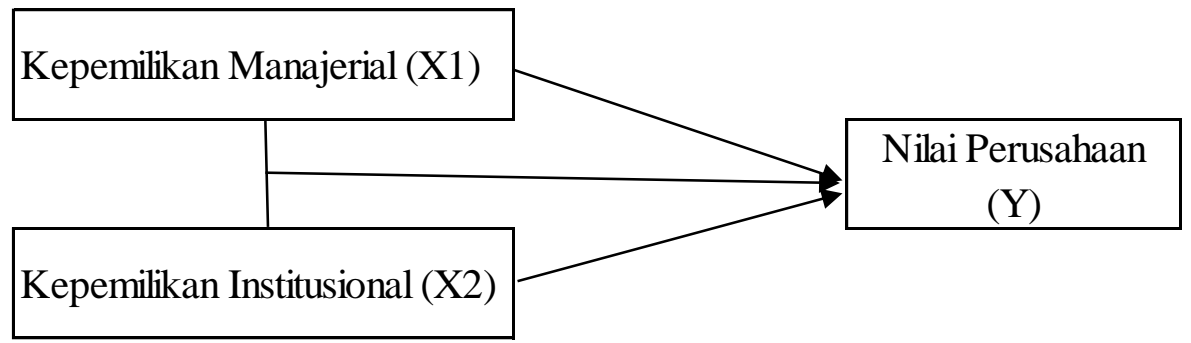

Gambar 1. Kerangka Konseptual Penelitian 


\section{METODE \\ Jenis Penelitian}

Metode dalam penelitian ini dilakukan dengan menggunakan metode kuantitatif berupa data laporan keuangan perusahaan yang diterbitkan oleh perusahaan manufaktur yang terdaftar di BEI (situs www.idx.id).

\section{Populasi dan Sampel Penelitian}

Populasi dalam penelitian ini adalah perusahaan manufaktur yang terdaftar di Bursa Efek Indonesia (BEI) tahun 2013 sampai dengan 2016. Sampel yang digunakan dalam penelitian ini adalah perusahaan manufaktur yang memiliki kriteria tertentu. Metode pengambilan sampel dilakukan dengan purposive sampling yaitu pengambilan sampel dilakukan berdasarkan kriteria tertentu (Sugiyono, 2014: 64) sebagai berikut: (1) Perusahaan manufaktur yang sudah terdaftar di Bursa Efek Indonesia (BEI) dari tahun 2013 sampai 2016. (2) Perusahaan yang menerbitkan laporan keuangan tahunan dengan periode yang berakhir 31 Desember. (3) perusahaan yang tersedia lengkap mengenai kepemilikan manajerial dan kepemilikan institusional.

\section{Metode Analisis Data}

\section{Pengujian Asumsi Klasik}

1. Pengujian Normalitas. Uji normalitas dilakukan untuk menguji apakah dalam suatu model regresi, variabel dependen, variabel independen atau keduanya memiliki distribusi data yang normal atau tidak. Untuk menguji normalitas peneliti akan menggunakan uji Kolmogorof-Smirnov. Uji ini dilakukan dengan membandingkan probabilitas yang diperoleh dengan taraf signifikansi $\alpha 0,05$. Apabila $p$ value $>\alpha$, maka data berdistribusi normal, jika $p$ value < $\alpha$ maka data tidak berdistribusi normal.

2. Multikolinieritas. Multikolinieritas adalah suatu keadaan yang menyatakan bahwa variabel-variabel independen dalam persamaan regresi mempunyai hubungan yang kuat satu sama lain. Uji multikolinieritas merupakan alat uji untuk mengetahui apakah dalam model regresi ditemukan adanya korelasi antara variabel-variabel independen. Uji multikolinieritas dilakukan dengan cara melihat nilai Variance Inflation Factor (VIF) dan dengan alat bantu program Statistical Product and Service Solution (SPSS) . Apabila nilai VIF kurang dari 10 dan nilai tolerance $>0,10$ maka tidak terdapat gejala multikolinieritas dan sebaliknya.

3. Uji heteroskedastisitas. Uji heterokedastisitas dilakukan untuk menguji apakah dalam sebuah model regresi terjadi ketidaksamaan varians residual dari satu pengamatan kepengamatan lain. Untuk mengetahui ada tidaknya heterokedastisitas dilakukan dengan melihat ada tidaknya pola tertentu pada grafik scatterplot. Jika terdapat pola tertentu yang teratur, maka mengindikasikan telah terjadi heteroskedastisitas. Jika tidak ada pola yang jelas dan titik-titik menyebar di atas dan dibawah angka 0 pada sumbu $\mathrm{Y}$, maka tidak terjadi heteroskedastisitas.

4. Autokorelasi. Autokorelasi adalah adanya korelasi antara data pada suatu waktu tertentu dengan nilai data tersebut pada waktu satu periode sebelumnya atau lebih pada data urut waktu. Dalam penelitian ini untuk menguji ada tidaknya autokorelasi baik positif atau negatif, peneliti menggunakan uji Durbin-Watson (D-W) dengan alat bantu SPSS, dengan membandingkan nilai Durbin Watson hitung (d) dengan nilai Durbin Watson table.

\section{Analisis Regresi Linier Berganda}

Analisis regresi linier berganda digunakan untuk mengetahui ada tidaknya pengaruh dari variabel bebas terhadap variabel terikat. Alat ukur yang digunakan untuk mengetahui hasil uji analisis regresi berganda adalah dengan menggunakan aplikasi SPSS yang kemudian di interpretasikan kedalam rumus yaitu:

$$
Y=a+b_{1} x_{1}+b_{2} x_{2}+e
$$




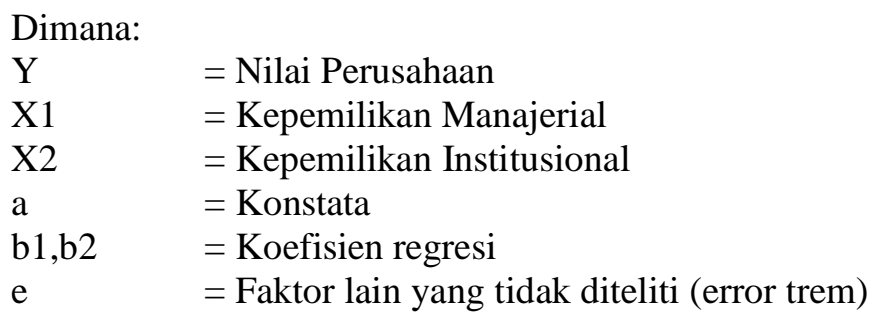

\section{Uji Hipotesis}

\section{Uji Secara Parsial (Uji Statistk t)}

Uji t digunakan untuk menguji signifikan hubungan antara variabel $\mathrm{X}$ danY, apakah $\mathrm{X} 1$ dan X2 (kepemilikan manajerial dan kepemilikan institusional) benar benar berpengaruh terhadap variabel Y (nilai perusahaan) secara terpisah atau parsial (Ghozali, $2006: 84$ ). Uji t dilakukan dengan menggunakan aplikasi SPSS Hipotesis yang digunakan dalam pengujian ini adalah: Apabila signifikansi $\mathrm{t}>0,05$, maka variabel bebas (kepemilikan manajerial dan kepemilikan isntitusional) tidak berpengaruh secara signifikan terhadap variabel terikat (nilai perusahaan) dan sebaliknya.

\section{Uji Secara Simultan (Uji Statistik F)}

Dalam penelitian ini, uji $\mathrm{F}$ digunakan untuk mengetahui tingkat siginifikansi pengaruh variabel-variabel independen secara bersama-sama (simultan) terhadap variabel dependen (Ghozali, 2006: 84). Dalam penelitian ini, hipotesis yang digunakan adalah: Apabila signifikansi $\mathrm{F}<0.05$, maka variabel-variabel bebas yaitu kepemilikan manajerial dan kepemilikan isntitusional berpengaruh signifikan secara bersama-sama terhadap variabel terikatnya yaitu nilai perusahaan begitupun sebaliknya.

\section{Uji Koefisien Determinasi}

Koefisien determinasi digunakan untuk mengukur seberapa jauh kemampuan model regresi dalam menerangkan variasi variabel dependen. Nilai adjusted $R^{2}$ memiliki range antara nol hingga satu. Nilai adjusted $\mathrm{R}^{2}$ yang makin mendekati nol berarti kemampuan variabelvariabel independen dalam menjelaskan variasi variabel dependen makin terbatas. Sementara nilai adjusted $\mathrm{R}^{2}$ yang makin mendekati satu berarti variabel-variabel independen makin memberikan semua informasi yang dibutuhkan untuk memprediksi variasi variabel dependen (Ghozali 2006: 83).

\section{HASIL DAN PEMBAHASAN}

\section{Hasil Pengujian Asumsi Klasik}

\section{Uji Normalitas}

Berdasarkan tabel 1 maka dapat dilihat bahwa variabel kepemilikan manajerial (X1) dan variabel kepemilikan institusional (X2) menunjukkan nilai Asymp. Sig. (2-tailed) lebih besar dari nilai 0.05 atau $5 \%$ yang telah tetapkan sehingga dapat disimpulkan bahwa penelitian ini berdistribusi normal.

Tabel. 1

Uji Normalitas

One-Sample Kolmogorov-Smirnov Test

\begin{tabular}{|l|r|r|r|}
\hline & $\begin{array}{c}\text { Kepemilikan } \\
\text { Manajerial }\end{array}$ & $\begin{array}{c}\text { Kepemilikan } \\
\text { Institusional }\end{array}$ & \multicolumn{1}{c|}{$\begin{array}{c}\text { Nilai } \\
\text { Perusahaan }\end{array}$} \\
\hline N & 72 & 72 & 72 \\
Normal Parameters $^{\mathrm{a}} \quad$ Mean & 34.6415 & 29.4379 & 1.6921 \\
\hline
\end{tabular}




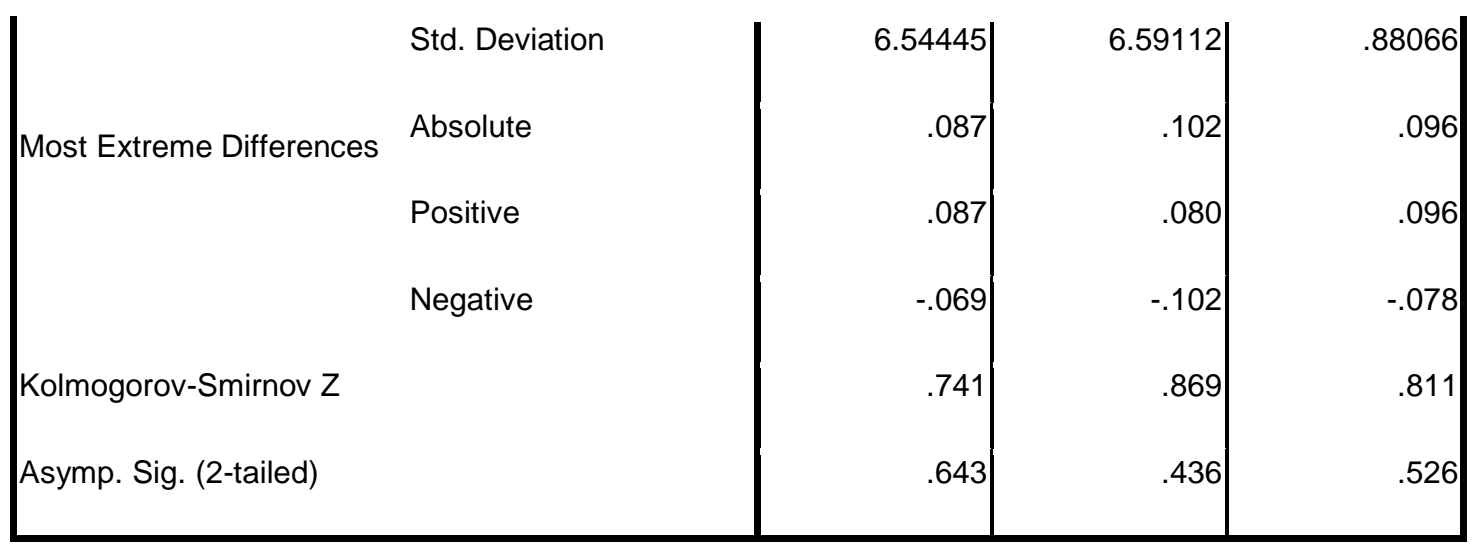

a. Test distribution is Normal.

\section{Uji Multikolinieritas}

Tabel .2

Uji Multikolinieritas

\begin{tabular}{|l|r|r|}
\hline \multicolumn{2}{|c|}{} & \multicolumn{2}{|c|}{ Collinearity Statistics } \\
\cline { 3 - 4 } Model & Tolerance & \multicolumn{1}{|c|}{ VIF } \\
\hline $1 \quad$ (Constant) & & \\
Kepemilikan Manajerial & .963 & 1.039 \\
Kepemilikan Institusional & .963 & 1.039 \\
\hline
\end{tabular}

zsBerdasarkan Tabel 2 menunjukkan nilai tolerance variabel kepemilikan manajerial (X1) adalah sebesar 0,963, nilai tolerance variabel Kepemilikan Institusional (X2) adalah sebesar 0,963 . Untuk nilai VIF variabel kepemilikan manajerial (X1) adalah sebesar 1,039, nilai VIF variabel variabel Kepemilikan Institusional (X2) adalah sebesar 1,039. Maka kedua variabel dalam penelitian ini memenuhi syarat tidak terjadi multikolinieritas.

\section{Uji Heteroskedastisitas}

Berdasarkan tabel 3 grafik scatterplot antara SRESID dan ZPRED dimana sumbu Y adalah $\mathrm{Y}$ yang telah diprediksi dan sumbu $\mathrm{X}$ adalah residual $(\mathrm{Y}$ prediksi dengan $\mathrm{Y}$ sesungguhnya) yang telah distandardized yang memperlihatkan titik menyebar secara acak, tidak membentuk pola tertentu yang jelas, tersebar baik keatas maupun kebawah angka nol pada sumbu Y. Hal ini dapat disimpulkan bahwa tidak terjadi heteroskedasitas pada model regresi dalam penelitian ini. 
Tabel. 3

Uji Heterokedastisitas

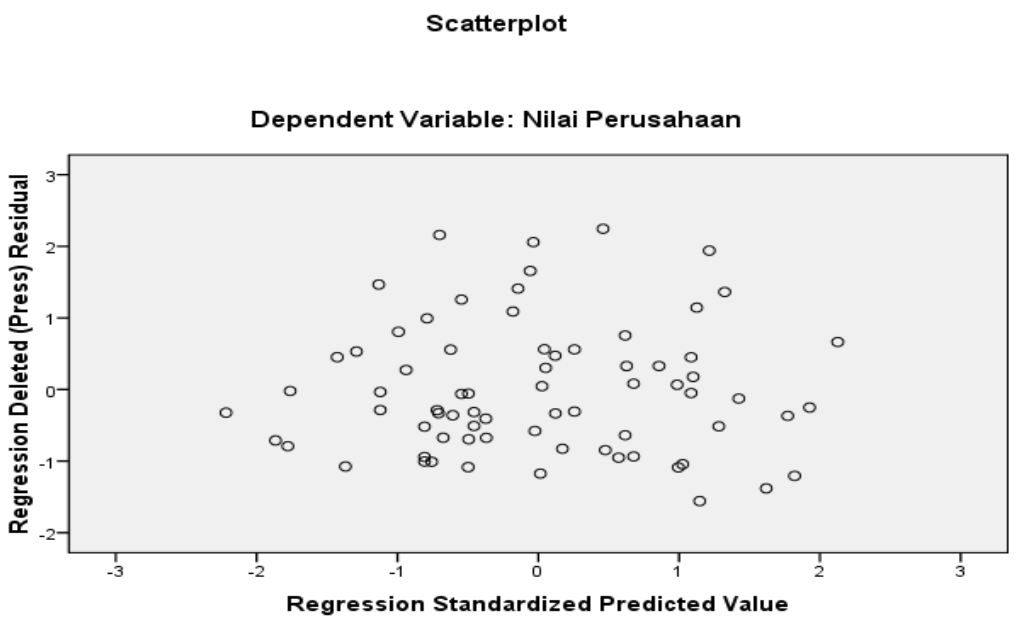

\section{Uji Autokorelasi}

Berdasarkan tabel 4 dapat dilihat bahwa nilai DW test sebesar 1,979 nilai ini akan dibandingkan dengan nilai pada tabel Durbin Watson dengan tingkat signifikansi sebesar 5\% jumlah sampel $(\mathrm{n})=72$ dan jumlah variabel yang memprediksi atau mempengaruhi variabel bebas $(\mathrm{k})=2$. Tingkat signifikansi sebesar $5 \%$ jumlah sampel $(\mathrm{n})=72$ dan jumlah variabel yang memprediksi atau mempengaruhi variabel terikat $(\mathrm{k})=2$ menunjukkan nilai batas atas $(\mathrm{du})=$ 1,6751, maka sesuai syarat $d u<d w<4$-du atau sama dengan $1,6751<1.979<2,3245$, maka model regresi penelitian ini tidak mengandung autokorelasi positif maupun negatif.

Tabel. 4

Uji Autokorelasi

Model Summary ${ }^{b}$

\begin{tabular}{|l|r|r|r|r|r|}
\hline Model & $\mathrm{R}$ & R Square & \multicolumn{1}{c|}{$\begin{array}{c}\text { Adjusted R } \\
\text { Square }\end{array}$} & $\begin{array}{l}\text { Std. Error of the } \\
\text { Estimate }\end{array}$ & Durbin-Watson \\
\hline 1 & $.431^{\mathrm{a}}$ & .371 & .201 & .88562 & 1.979 \\
\hline
\end{tabular}

Predictors: (Constant), Kepemilikan Institusional, Kepemilikan Manajerial

Dependent Variable: Nilai Perusahaan

Analisis RegresiLinear Berganda

Tabel. 5

Hasil Uji Regresi Linear Berganda Coefficients $^{\mathrm{a}}$

\begin{tabular}{|c|c|c|c|c|c|}
\hline & \multicolumn{2}{|c|}{ Unstandardized Coefficients } & $\begin{array}{c}\text { Standardized } \\
\text { Coefficients }\end{array}$ & & \\
\cline { 2 - 4 } Model & B & Std. Error & Beta & $\mathrm{t}$ & Sig. \\
\hline
\end{tabular}




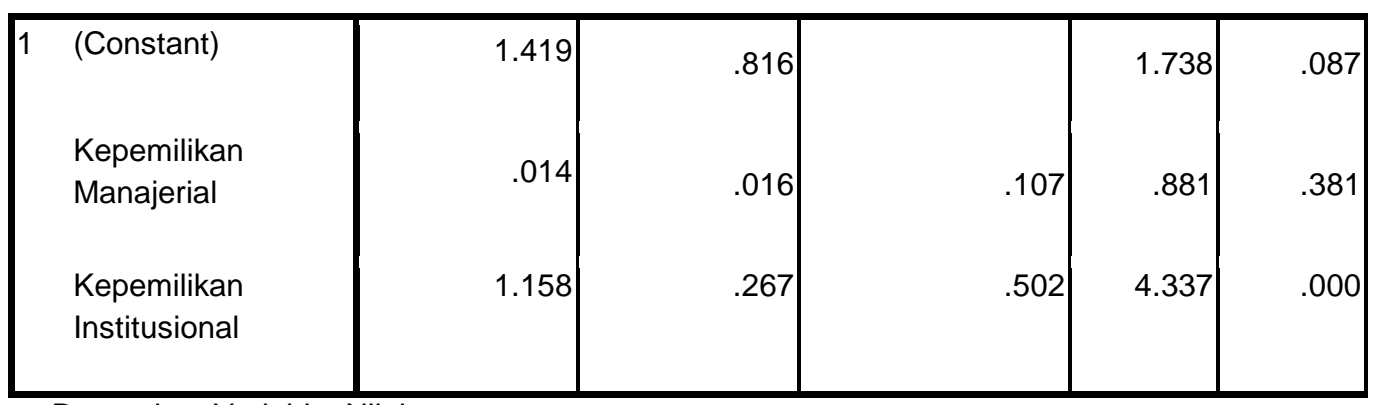

a. Dependent Variable: Nilai

Perusahaan

Analisis linear regresi berganda berfungsi untuk menganalisis hubungan dan pengaruh antara satu variabel terikat terhadap dua/lebih variabel bebas. Berdasarkan uji regresi berganda yang dilakukan dapat dilihat pada Tabel 5, maka diperoleh persamaan regresi bergandanya adalah:

$\mathrm{Y}=1,419+0,014 \mathrm{X}_{1}+1,158 \mathrm{X}_{2}+\mathrm{e}$

1. Nilai constanta adalah $=1,419$ artinya jika tidak terjadi perubahan (konstan) variabel kepemilikan manajerial dan kepemilikan institusional (nilai $\mathrm{X}_{1}$ dan $\mathrm{X}_{2}$ adalah 0) maka nilai perusahaan sebesar 1,419 .

2. Nilai koefisien regresi variabel kepemilikan manajerial sebesar 0,014 artinya jika variabel kepemilikan manajerial $\left(\mathrm{X}_{1}\right)$ meningkat sebesar 1 (satuan) dengan asumsi variabel institusional $\left(\mathrm{X}_{2}\right)$ dan konstanta (a) adalah 0 (nol), maka nilai perusahaan minat meningkat sebesar 0,014 .

3. Nilai koefisien regresi variabel kepemilikan institusional sebesar 1,158 artinya jika variabel kepemilikan institusional $\left(\mathrm{X}_{2}\right)$ meningkat sebesar 1 (satuan) dengan asumsi variabel kepemilikian manajerial $\left(\mathrm{X}_{1}\right)$ dan konstanta (a) adalah 0 (nol), maka nilai perusahaan menurun sebesar 1,158 .

\section{Uji Hipotesis}

1. Uji t

Pada tabel 5 dapat dilihat bahwa nilai sig variabel kepemilikan manajerial adalah 0,381 > 0,05, maka dapat disimpulkan bahwa Variabel kepemilikan manajerial $\left(\mathrm{X}_{1}\right)$ tidak berpengaruh signifikan terhadap nilai perusahaan pada perusahaan manufaktur di Bursa Efek Indonesia. Sedangkan nilai sig kepemilikan institusional adalah $0,000<0,05$, maka dapat disimpulkan bahwa kepemilikian institusional (X2) berpengaruh signifikan terhadap nilai perusahaan pada perusahaan manufaktur di Bursa Efek Indonesia.

Tabel. 5

Hasil Uji t (Parsial)

Coefficients $^{\mathrm{a}}$

\begin{tabular}{|l|c|c|c|c|c|}
\hline \multirow{2}{*}{ Model } & \multicolumn{2}{|l|}{ Unstandardized Coefficients } & $\begin{array}{c}\text { Standardized } \\
\text { Coefficients }\end{array}$ & & \\
\cline { 2 - 4 } & B & Std. Error & Beta & $\mathrm{t}$ & Sig. \\
\hline
\end{tabular}




\begin{tabular}{|l|r|r|r|r|r|}
\hline 1.419 & .816 & & 1.738 & .087 \\
$\begin{array}{l}\text { Kepemilikan } \\
\text { Manajerial }\end{array}$ & .014 & .016 & .107 & .881 & .381 \\
\hline $\begin{array}{l}\text { Kepemilikan } \\
\text { Institusional }\end{array}$ & 1.158 & .267 & .502 & 4.337 & .000 \\
\hline
\end{tabular}

\section{Uji F}

Uji $\mathrm{F}$ adalah bagian uji statistik yang digunakan untuk membuktikan pengaruh variabel independent terhadap variabel dependent secara bersama-sama (simultan). Berdasarkan hasil pengujian pada tabel 6 dapat dilihat pada nilai sig adalah $0,000<0,05$, maka dapat disimpulkan bahwa kepemilikan manajerial (X1) dan kepemilikan institusional (X2) secara bersama-sama berpengaruh signifikan terhadap nilai perusahaan pada perusahaan manufaktur di Bursa Efek Indonesia.

Tabel. 6

Hasil Uji F

ANOVA $^{\text {D }}$

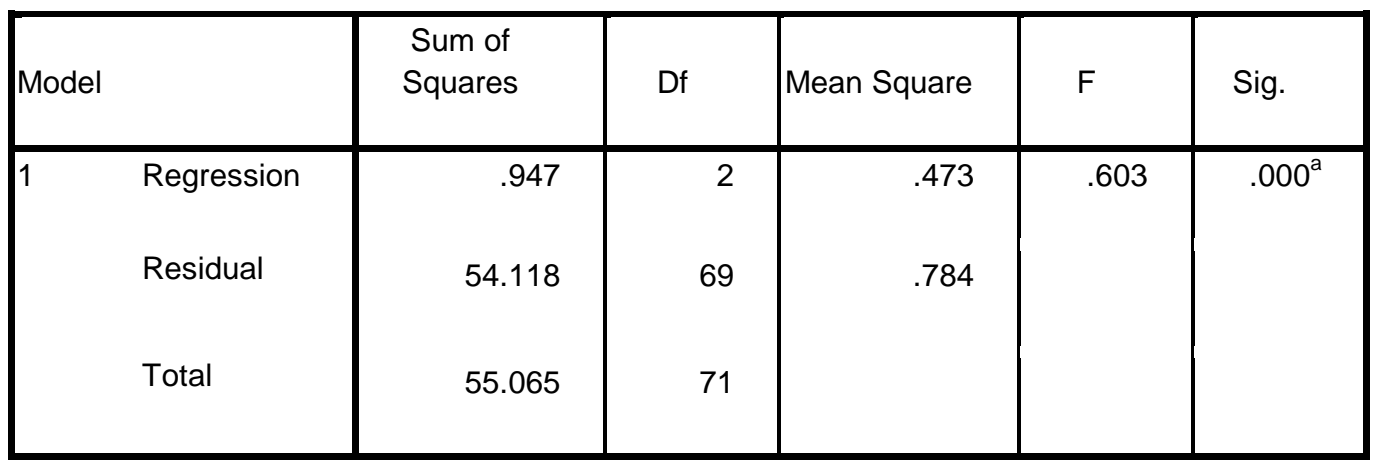

a. Predictors: (Constant), Kepemilikan Institusional, Kepemilikan Manajerial

b. Dependent Variable: Nilai Perusahaan

\section{Uji Koefisien Determinasi}

Koefisien determinasi bertujuan untuk mengetahui seberapa besar kemampuan variabel bebas menjelaskan variabel teriakat. Berdasarkan tabel 7 dapat dilihat bahwa nilai koefisien determinasi terdapat pada nilai Adjusted $R$ Square dengan sebesar 0,201. Hal ini berarti kemampuan variabel kepemilikan manajerial dan kepemilikan institusional dalam menjelaskan variabel terikat adalah sebesar $20,1 \%$ sisanya $79,9 \%$ dijelaskan oleh variabel lain yang tidak dibahas dalam penelitian ini.

Tabel. 7

Koefisien Determinasi

Model Summary

\begin{tabular}{|l|l|l|l|l|l|}
\hline Model & $R$ & $R$ Square & $\begin{array}{c}\text { Adjusted R } \\
\text { Square }\end{array}$ & $\begin{array}{c}\text { Std. Error of } \\
\text { the Estimate }\end{array}$ & $\begin{array}{c}\text { Durbin- } \\
\text { Watson }\end{array}$ \\
\hline
\end{tabular}




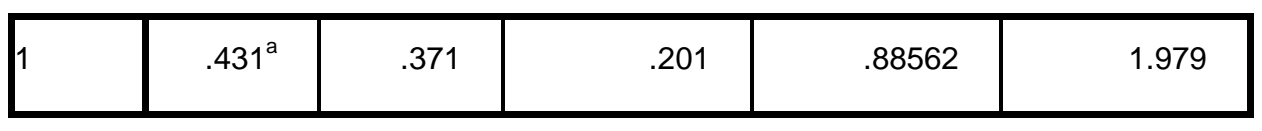

dictors: (Constant), Kepemilikan Institusional, Kepemilikan Manajerial

dependent Variable: Nilai Perusahaan

\section{Pembahasan}

\section{Pengaruh Kepemilikan Manajerial Terhadap Nilai Perusahaan}

Hasil penelitian ini menunjukkan bahwa nilai sig variabel kepemilikan manajerial adalah 0,381 $>0,05$, maka dapat disimpulkan bahwa Variabel kepemilikan manajerial $\left(\mathrm{X}_{1}\right)$ tidak berpengaruh signifikan terhadap nilai perusahaan pada perusahaan manufaktur di Bursa Efek Indonesia. Hal ini juga dapat menunjukkan bahwa semakin tinggi kepemilikan manajerial tidak berarti bahwa nilai perusahaan akan semakin meningkat pula. Karena sebagai seorang pemilik, seorang manajer tetap tidak boleh mengambil keputusan sendiri. Seorang manajer sekaligus pemilik tetap harus mempertimbangkan kebijakan dari para pemilik saham yang lain. Hasil ini mendukung penelitian yang dilakukan rachmawati dan Triatmoko (2007), tetapi tidak mendukung penelitian sebelumnya yang dilakukan Kawatu (2009) dan Angraheni (2010) yang menyatakan bahwa kepemilikan manajerial berpengaruh terhadap nilai perusahaan.

\section{Pengaruh Kepemilikan Institusional Terhadap Nilai Perusahaan}

Hasil penelitian ini menunjukkan bahwa nilai sig kepemilikan institusional adalah $0,000<0,05$, maka dapat disimpulkan bahwa kepemilikian institusional (X2) berpengaruh signifikan terhadap nilai perusahaan pada perusahaan manufaktur di Bursa Efek Indonesia. Dengan demikian, semakin besar kepemilikan institusional merupakan salah satu cara untuk mengurangi agency conflict. Ini terbukti dengan tingginya tingkat kepemilikan konstitusional pada perusahaan, maka monitoring pihak eksternal terhadap perusahaan semakin kuat, sehingga dapat mengurangi agency cost yang terjadi didalam perusahaan dan juga dapat meningkatkan nilai perusahaan. Dengan kata lain, tingkat kepemilikan institusional yang tinggi akan menimbulkan usaha pengawasan yang lebih besar oleh pihak investor institusional sehingga dapat menghalangi perilaku oportunistik manajer hal ini diduga akan membuat proses pengambilan keputusan bisnis lebih baik.

\section{Pengaruh Kepemilikan Manajerial dan Institusional Terhadap Nilai Perusahaan}

Hasil penelitian ini menunjukkan bahwa nilai sig adalah $0,000<0,05$, maka dapat disimpulkan bahwa kepemilikan manajeria (X1) dan kepemilikan institusional (X2) secara bersama-sama (simultan) berpengaruh signifikan terhadap nilai perusahaan pada perusahaan manufaktur di Bursa Efek Indonesia. Dengan demikian, jika seorang manajer sekaligus sebagai pemilik menjalankan perusahaan dengan baik karena seorang manajer sadar bahwa baik atau buruknya perusahaan akan sangat berdampak kepada pendapatannya. Serta dari pihak institusional tidak lupa untuk memonitoring dengan baik secara berkala maka perusahaan akan dapat berjalan dengan baik sehingga nilai perusahaan akan semakin meningkat.

\section{SIMPULAN}

1. Variabel kepemilikan manajerial adalah 0,381 >0,05, maka dapat disimpulkan bahwa Variabel kepemilikan manajerial $\left(\mathrm{X}_{1}\right)$ tidak berpengaruh signifikan terhadap nilai perusahaan pada perusahaan manufaktur di Bursa Efek Indonesia

2. kepemilikan institusional adalah $0,000<0,05$, maka dapat disimpulkan bahwa kepemilikian institusional (X2) berpengaruh signifikan terhadap nilai perusahaan pada perusahaan manufaktur di Bursa Efek Indonesia

3. Secara bersama-sama (simultan) kepemilikan manajeria (X1) dan kepemilikan institusional (X2)) berpengaruh signifikan terhadap nilai perusahaan pada perusahaan manufaktur di Bursa Efek Indonesia dimana nilai sig 0,000<0,05. 


\section{SARAN}

Disarankan kepada perusahaan manufaktur agar memiliki saham dari pihak institusional, karena dari hasil penelitian yang diperoleh semakin tinggi kepemilikan institusional maka monitoring semakin baik sehingga nilai perusahaan juga akan meningkat. Penggunaan sampel yang digunakan lebih bervariasi bukan dari jenis perusahaan manufaktur saja tetapi berasal dari semua jenis perusahaan publik. Variabel dalam penelitian ini terlalu sedikit, maka untuk peneliti selanjutnya diharapkan menambah variabel agar penelitan selanjutnya dapat lebih bervariasi dan lebih luas.

\section{DAFTAR PUSTAKA}

Boediono, Gideon. 2005. Pengaruh Mekanisme Corporate Governance dan Dampak Manajemen Laba dengan Menggunakan Analisis Jalur. Simposium Nasional Akuntansi (SNA) VIII Solo.

Ghozali, Imam. 2011. Aplikasi Analisis Multivariate dengan Program SPSS. Semarang:

Badan Penerbit Universitas Diponegoro.

Pakaryaningsih, Elok. 2008. Peranan Kepemilikan Institusional Terhadap Nilai Perusahaan Dalam Tinjauan Hubungan Non-Linear Kasus Perusahaan Yang Terdaftar Di Bursa Efek Indonesia. Jurnal Manajemen dan Bisnis. Vol. 12. No. 2.

Tarjo. 2011. Corporate Governance, Ukuran Perusahaan, Dan Leverage Terhadap Manajemen Laba Perusahaan Manufaktur Indonesia. Vol.8 No.1

Sofyaningsih dan Hardiningsih. 2011. Struktur Kepemilikan, Kebijakan Dividen, Kebijakan Utang Dan Nilai Perusahaan. Jurnal Ekonomi, vol.3 No. 1

Sugiyono. 2014. Metode Penelitian Administrasi. Bandung: CV Alfabeta. 